\title{
Pengaruh Corporate Sosial Responsibility (CSR) terhadap Nilai Perusahaan pada Perusahaan Konstruksi yang Terdaftar di Bursa Efek Indonesia (BEI)
}

\author{
Oleh: \\ Rendi Siswanto ${ }^{1)}$, Budi Yanti ${ }^{2}$ \\ 123)Fakultas Ekonomi Universitas Taman Siswa Padang \\ Rendi.siwanto10@gmail.com, budiyantibudi04@gmail.com
}

\begin{abstract}
Abstrak
Tujuan penelitian ini untuk mengetahui pengaruh Corporate Social Responsibilty (CSR) terhadap nilai perusahaan pada perusahaan konstruksi yang terdaftar di Bursa Efek Indonesia (BEI). Metode penelitian yang digunakan adalah kuantitatif. Variabel dalam penelitian ini yaitu Corporate Social Responsibility (X) dan Nilai Perusahaan (Y). Teknik pengambilan sampel yang digunakan adalah total sampling dimana jumlah sampel sama dengan populasi, metode pengumpulan data yang digunakan adalah regresi linear sederhana, uji t, uji $F$ dan koefisien determinan $\left(R^{2}\right)$. Berdasarkan hasil uji yang dilakukan secara parsial dan simultan variabel Corporate Social Responsibilty (CSR) terdapat pengaruh yang negatif dan signifikan terhadap nilai perusahaan pada perusahaan konstruksi yang terdaftar di Bursa Efek Indonesia (BEI) karena nilai signifikan $<0,05$. Sementara nilai koefisien determinasi terdapat pada nilai adjusted $R^{2}$ sebesar $19,3 \%$ sisanya $80,7 \%$ dijelaskan oleh variabel lain yang tidak dibahas dalam penelitian ini.
\end{abstract}

Kata kunci: Corporate Social Responsibilty (CSR) dan Nilai Perusahaan

\section{PENDAHULUAN}

Saat ini industri konstruksi di Indonesia semakin berkembang dan kebanyakan perusahaan masih fokus hanya pada pencarian keuntungan. Ketatnya persaingan seringkali menjadi alasan utama oleh perusahaan untuk menghalalkan segala cara untuk menekan biaya serendah-rendahnya dan meraih keuntungan yang tinggi.

Disaat banyaknya perusahaan yang semakin berkembang, maka pada saat itu pula kesenjangan dan kerusakan lingkungan sekitarnya dapat terjadi, oleh karena itu muncul kesadaran untuk mengatasi dampak negatif yang ditimbulkan tersebut.
Dewasa ini, banyak perusahaan yang menerapkan program corporate social responsibility (CSR). Penerapan CSR pada saat sekarang ini sudah dianggap sebagai sebuah investasi perusahaan.

Suatu perusahaan memang tidak dapat dipisahkan dari tanggung jawabnya terhadap sosial dan lingkungan. Banyak perusahaan yang seakan berlomba meng- expose diri dalam kegiatan yang berorientiasi sosial, seperti PT. Media Group dengan program "Peduli Tsunami Aceh dan Nias", PT. Unilever Indonesia dengan program "Lifebouy Hand Washing Campaign dan "Rinso, Bersih Itu Baik", PT. Kalbe Farma dengan program "Puskesmas 
Keliling Procold", AQUA dengan program " $1=10$ Liter", serta banyak lagi program sosial yang memiliki program CSR yang beragam. Namun di sisi lain, PT. Lapindo Brantas meninggalkan kenangan buruk pada para korban lumpur yang harus kehilangan tempat tinggal, harta benda, dan pekerjaan akibat eksploitasi gas. Bencana memaksa penduduk harus ke rumah sakit, sedangkan perusahaan terkesan lebih mengutamakan penyelamatan asetasetnya daripada mengatasi soal lingkungan dan sosial yang ditimbulkan. Peristiwa tersebut merupakan salah satu contoh yang menunjukkan lemahnya pelaksanaan CSR di Indonesia.

Penelitian Pfleiger et al (2005) menunjukkan bahwa usaha-usaha pelestarian lingkungan oleh perusahaan akan mendatangkan beberapa keuntungan, diantaranya adalah ketertarikan pemegang saham dan stakeholder terhadap keuntungan yang diperoleh perusahaan akibat pengelolaan lingkungan yang bertanggung jawab

Wirakusuma (2008) hasil penelitiannya menunjukkan bahwa profitabilitas berpengaruh terhadap nilai perusahaan, sedangkan Suranta (2007) menemukan CSR berpengaruh positif terhadap nilai perusahaan, Nurlela dan Islahuddin hasil penelitian menunjukkan bahwa corporate social responsibility, persentase kepemilikan, serta interaksi antara corporate social responsibility dengan presentase kepemilikan manajemen secara simultan berpengaruh signifikan terhadap nilai perusahaan. Pada sisi lain penelitian yang disebutkan dalam Yusrina (2010) meneliti tentang pengaruh leverage dan profitabilitas terhadap CSR pada perusahaan manufaktur yang terdaftar di BEI. Yang menunjukkan bahwa leverage dan profitabilitas berpengaruh negatif terhadap pengungkapan CSR.

Tujuan penelitian ini adalah "Untuk mengetahui dan menganalisis pengaruh corporate social responsibility (CSR) terhadap nilai perusahaan pada perusahaan konstruksi yang terdafatar di Bursa Efek Indonesia.".

\section{Rumusan Masalah}

Berdasarkan latar belakang yang telah diuraikan, Corporate Social Responsibility dapat digunakan untuk meningkatkan nilai perusahaan. Dimana dengan adanya CSR akan meningkatkan kepercayaan masyarakat dan para pemegang saham terhadap perusahaan. Untuk itu, perumusan masalah dalam penelitian ini adalah "Bagaimanakah pengaruh Corporate Social Responsibility terhadap nilai perusahaan pada perusahaan konstruksi yang terdafatar di Bursa Efek Indonesia?"

\section{Tujuan Penelitian}

Tujuan penelitian ini adalah "Untuk mengetahui dan menganalisis pengaruh corporate social responsibility (CSR) terhadap nilai perusahaan pada perusahaan konstruksi yang terdafatar di Bursa Efek Indonesia."

\section{LANDASAN TEORI}

\section{Kinerja Perusahaan}

Kinerja perusahaan adalah kemampuan perushaan dalam menjalankan operasionalnya. 
Informasi mengenai kinerja sangat bermanfaat bagi pengguna laporan keuangan. Bagi kelompok investor, kreditor maupun masyarakat umum menginginkan investasi mereka yang ditanamkan ke bank perlu untuk mengetahui kinerja bank tersebut. Pengembalian atas investasi modal berguna bagi evaluasi manajemen, analisis profitabilitas, peramalan laba, serta perencanaan dan pengendalian. Menggunakan angka pengembalian atas investasi modal untuk tujuan tersebut membutuhkan pemahaman mendalam mengenai ukuran pengembalian ini. Karena ukuran pengembalian mencakup komponen yang berpotensi memberikan kontribusi pada pemahaman kinerja perusahaan (Wild, Subramanyam, Halsey, 2007).

\section{Nilai Perusahaan}

\section{Pengertian Nilai Perusahaan}

Menurut Rika dan Islahuddin (2008), nilai perusahaan didefinisikan sebagai nilai pasar, karena nilai pasar perusahaan dapat memberikan kemakmuran pemegang saham secara maksimum apabila harga saham perusahaan meningkat. Semakin tinggi harga saham, maka semakin tinggi kemakmuran pemegang saham. Nilai perusahaan dapat dicapai dengan maksimum jika para pemegang saham menyerahkan urusan pengelolaan perusahaan kepada orangorang yang berkompeten dalam bidangnya, seperti manajer ataupun komisaris.

\section{Tujuan Nilai Perusahaan}

Suatu nilai perusahaan dapat tercermin dari harga sahamnya. Harga pasar saham yang terbentuk antara pembeli dan penjual disaat terjadi transaksi disebut nilai pasar perusahaan, karena harga pasar saham dianggap cerminan dari nilai asset perusahaan sesungguhnya. Nilai perusahaan yang dibentuk melalui indikator nilai pasar saham sangat dipengaruhi oleh peluang-peluang investasi. Adanya peluang investasi memberikan sinyal positif tentang pertumbuhan perusahaan dimasa yang akan datang, sehingga akan meningkatkan harga saham, dengan meningkatnya harga saham, maka nilai perusahaanpun akan meningkat.

Corporate Social Responsibility ( Tanggung Jawab Sosial Perusahaan )

\section{Pengertian CSR}

Tanggung jawab sosial dari perusahaan terjadi antara sebuah perusahaan dengan semua stakeholder, termasuk didalamnya pelanggan, pegawai, komunitas, investor atau pemilik, pemerintah, supplier bahkan juga competitor. CSR sebagai sebuah gagasan perusahaan tidak lagi dihadapkan pada tanggung jawab yang berpijak pada single bottom line, yaitu nilai perusahaan yang direfleksikan dalam kondisi keuangan (financial) saja. Tapi tanggung jawab perusahaan harus berpijak pada triple bottom line. Disini bottom lines lainnya selain keuangan juga ada sosial dan lingkungan. Karena kondisi keuangan saja tidak cukup menjamin nilai perusahaan tumbuh secara berkelanjutan (Samsinar, Haerani dan Pagalung. 2009)

\section{Latar Belakang Corporate Social Responsibility}

Menurut Gray et al dalam Yuliana, Purnomosidhi, dan Sukoharsono 2008), mengemukakan beberapa teori yang melatarbelakangi 
perusahaan untuk melakukan pengungkapan sosial, yaitu :

\section{Decision Usefulness Studies}

Teori ini memasukkan para pengguna laporan akuntansi yang lain selain para investor kedalam kriteria dasar pengguna laporan akuntansi sehingga suatu pelaporan akuntansi dapat berguna untuk pengambilan keputusan ekonomi oleh semua unsur pengguna laporan tersebut. Beberapa peneliti melakukan studi dan menemukan bukti bahwa informasi sosial dibutuhkan oleh pengguna. Studi tersebut meminta para analisis, banker, dan pihak lain yang terlibat untuk memberikan peringkat terhadap informasi akuntansi. Informasi akuntansi tersebut tidak terbatas pada informasi yang telah dikenal selama ini, melainkan juga memuat informasi lain yang relatif baru dalam wacana akuntansi.

\section{Economic Theory Studies}

Studi berdasarkan economic agency theory. Teori tersebut membedakan antara pemilik perusahaan dan menyiratkan bahwa pengelola perusahaan harus memberikan laporan pertanggungjawaban atas segala sumber daya yang dimiliki dan dikelolanya kepada pemilik perusahaan. Selanjutnya frase pemilik perusahaan mengalami perkembangan lebih lanjut, tidak hanya memiliki modal (shareholder) tetapi juga meluas keunsur stakehoders lainnya, yaitu masyarakat luas termasuk pemerintah dan lingkungan alam. Hal tersebut mengakibatkan perusahaan juga dituntut untuk membuat pelaporan yang lengkap untuk memenuhi kebutuhan informasi bagi stakehoders tersebut.

3. Social and Political Studies Sektor ekonomi tidak hanya dapat dipisahkan dari kehidupan politik, sosial, dan kerangka institusional tempat ekonomi berada. Studi sosial dan politik mencakup dua teori utama, yaitu : pertama, Stakeholder Theory yang mengasumsikan bahwa eksistensi perusahaan ditentukan oleh para stakehoders. Fokus utama dalam teori ini yaitu bagaimana perusahaan memonitor dan merespon kebutuhan para stakehoders-nya. Kedua,Legitimacy Theoryyang menyatakan bahwa perusahaan harus dapat menyesuaikan diri dengan sistem nilai yang telah diterapkan oleh masyarakat. Usaha perusahaan antara lain diwujudkan melalui pengungkapan sosial. Hal tersebut dilaksanakan dengan tujuan agar aktivitas dan keberadaan perusahaan terlegetimasi dimata masyarakat.

\section{Indikator - Indikator Corporate Social Responsibility}

Informasi mengenai CSR berdasarkan standar GRI (Global Reporting Initiative). GRI terdiri dari 79 pengungkapan:

1) Indikator Kinerja Ekonomi (economic performance indicator), terdiri dari 9 item.

Dimensi ekonomi menyangkut keberlanjutan organisasi berdampak pada kondisi ekonomi dari stakeholder dan sistem ekonomi pada tingkat lokal, nasional, dan tingkat global. Indikator ekonomi menggambarkan:

- Arus modal diantara berbagai pemangku kepentingan; dan 
- Dampak ekonomi utama dari organisasi seluruh masyarakat.

Kinerja keuangan merupakan hal yang mendasar untuk memahami organisasi dan keberlanjutannya.

2) Indikator kinerja lingkungan (environment performance indicator), 30 item

Dimensi lingkungan menyangkut keberlanjutan organisasi berdampak pada kehidupan didalam sistem alam, termasuk ekosistem, tanah, udara, dan air. Indikator kinerja lingkungan terkait dengan input (bahan, energi, air) dan output (emisi/gas, limbah sungai, limbah kering/sampah). Selain itu, kinerja mereka mencakup kinerja yang berkaitan dengan keanekaragaman hayati, kepatuhan lingkungan, dan informasi yang berkaitan lainnya seperti limbah lingkungan dan dampak dari produk dan jasa.

3) Indikator Kinerja Sosial (social performance indicator) 40 item, terdiri dari:

- Tenaga Kerja (labor practices and decent work)

- Hak Asasi Manusia (human rights performance)

- Sosial (Society)

- Tanggung Jawab Produk (Product responsibility performance)

\section{Kerangka konseptual penelitian}

Berdasarkan penjelasan yang telah diuraikan diatas, maka variabel yang terkait didalam penelitian ini dapat digambarkan dalam suatu kerangka pemikira

Gambar 2.1

Kerangka Pemikiran

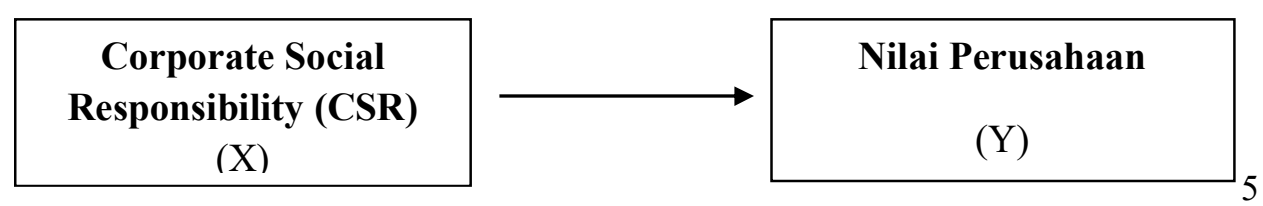

Program Studi Manajemen Fakultas Ekonomi Unitas Padang
Dimensi sosial menyangkut keberlanjutan sebuah organisasi telah berdampak di dalam sistem sosial yang beroperasi. Indikator kinerja sosial GRI mengidentifikasi kunci aspek kinerja yang meliputi praktek perburuhan/tenaga kerja, hak asasi manusia, masyarakat/sosial, dan tanggung jawab produk (www.globalreporting.org)

$\begin{aligned} & \text { Pengaruh Corporate } \\ & \text { Responsibility terhadap }\end{aligned}$ Nilai
Perusahaan Secara Teoritis
Pertanggungjawaban sosial
perusahaan diungkapkan dalam
Sustainability Reporting (laporan
keberlanjutan). CSR dapat menjadi
keberlanjutan apabila program yang
dibuat oleh suatu perusahaan benar-
benar merupakan komitmen bersama
dari segenap unsur yang ada di dalam
perusahaan itu sendiri. Tentunya
tanpa adanya komitmen dan
dukungan dengan penuh antusias dari
karyawan akan menjadikan program-
program tersebut bagaikan program
penebusan dosa dari pemegang saham
belaka. Dengan melibatkan karyawan
secara intensif, maka nilai dari
program-program tersebut akan
memberikan arti tersendiri yang
sangat besar bagi perusahaan.


Hipotesis (atau ada pula yang menyebutnya dengan istilah hipotesa) dapat diartikan secara sederhana sebagai dugaan sementara. Hipotesis berasal dari bahasa Yunani hypo yang berarti di bawah dan thesis yang berarti pendirian, pendapat yang ditegakkan, kepastian. Jika dimaknai secara bebas, maka hipotesis berarti pendapat yang kebenarannya masih diragukan. Untuk bisa memastikan kebenaran dari pendapat tersebut, maka suatu hipotesis harus diuji atau dibuktikan kebenarannya.

Untuk membuktikan kebenaran suatu hipotesis, seorang peneliti dapat dengan sengaja menciptakan suatu gejala, yakni melalui percobaan atau penelitian. Jika sebuah hipotesis telah teruji kebenarannya, maka hipotesis akan disebut teori. Dalam penelitian ini hipotesisnya adalah sebagai berikut :

\section{H1 : Diduga Corporate Social Responsibility (CSR) berpengaruh secara signifikan terhadap nilai perusahaan.}

\section{METODA PENELITIAN}

\section{Jenis dan Sumber Data}

Menurut Danang Sunyoto (2013:2), jenis data yang digunakan untuk mendukung penelitian ini sebagai berikut :

1. Data Kualitatif

Data kualitatif adalah data yang berhubungan dengan kategorisasi, kaakterisitik berwujud pertanyaan atau berupa kata-kata. Adapun data kualitatif pada penelitian ini adalah tentang gambaran umum organisasi yang diteliti.
2. Data Kuantitatif

Data kuantitatif adalah data yang berwujud angka-angka atau data yang diukur dalam suatu skala numeric, dalam penelitian ini data kuantitatifnya adalah laporan tahunan perusahaan konstruksi yang terdaftar di Bursa Efek Indonesia dan data-data lainnya selama periode pengamatan diperoleh dari Indonesia Capital Market Directory (ICMD)

Menurut Sugiyono (2012:137), sumber data yang digunakan untuk mendukung penelitian inin sebagai berikut :

1. Data Sekunder

Data sekunder adalah data yang diperoleh melalui berbagai sumber berupa laporan keuangan perbankan antara lain di Bursa Efek Indonesia dan studi kepustakaan yang relevan dibidang keuangan, seperti buku, jurnal, majalah dari internet atau website yang menunjang penelitian ini

\section{Populasi dan Sampel}

Populasi yang digunakan dalam penelitian ini adalah perusahaan-perusahaan konstruksi yang terdaftar di BEI (Bursa Efek Indonesia) selama 2012 - 2016.

Pengambilan sampel pada penelitian ini dilakukan dengan teknik total sampling. Total Sampling adalah teknik pengambilan sampel dimana jumlah sample sama dengan populasi (Sugiono, 2007)

Adapun kriteria sampel yang akan digunakan adalah sebagai berikut: 
1. Perusahaan kontruksi yang terdaftar di BEI untuk tahun 2012 2016.

2. Menerbitkan laporan tahunan lengkap selama tahun 2012 - 2016.

3. Perusahaan yang melakukan pengungkapan tanggung jawab sosial (CSR disclosure) dalam laporan tahunan tahun 2012 sampai tahun 2016.

4. Perusahaan yang pada tahun tertentu tidak memenuhi salah satu kriteria yang telah ditetapkan maka perusahaan tersebut tidak dimasukkan ke dalam sampel penelitian

\section{Defenisi Operasional}

Penelitian ini menggunakan
variabel Corporate Social Responsibility sebagai variabel independen. Pengungkapan tanggung jawab sosial merupakan data yang diungkap oleh perusahaan berkaitan dengan aktivitas sosialnya yang meliputi tema lingkungan, energi, kesehatan dan keselamatan tenaga kerja, lain-lain tentang tenaga kerja, produk, keterlibatan masyarakat dan umum. Pengungkapan CSR ini diukur dengan corporate social responsibility index (indeks CSR).

Content analysis adalah salah satu metode pengukuran CSR yang sudah banyak digunakan dalam penelitian-penelitian sebelumnya. Pendekatan ini pada dasarnya menggunakan pendekatan dikotomi yaitu setiap item CSR dalam instrumen penelitian diberi nilai 1 jika diungkapkan, dan nilai 0 jika tidak diungkapkan (Haniffa et al., 2005). Selanjutnya, skor dari setiap item dijumlahkan untuk memperoleh keseluruhan skor untuk setiap perusahaan.

\begin{abstract}
Penghitungan indeks CSR dilakukan dengan menggunakan pendekatan dikotomi, yaitu setiap item CSR dalam instrumen penelitian diberi nilai 1 jika diungkapkan dan nilai 0 jika tidak diungkapkan (Haniffa et al., 2005 dalam Fitri, 2009).
\end{abstract}

Merupakan variabel yang dipengaruhi atau menjadi akibat karena adanya variabel lain. Dalam penelitian ini, nilai perusahaan merupakan variabel dependennya yang disimbolkan dengan (Y). Nilai perusahaan dalam penelitian ini didefinisikan sebagai nilai pasar. Salah satu alternatif yang digunakan untuk menghitung nilai perusahaan dengan menggunakan Tobin's Q. Rasio ini dikembangkan oleh James Tobin.

\section{Teknik Analisis Penelitian}

\section{Statistik Deskriptif}

Didalam penelitian ini statistik deskriptif digunakan untuk melihat tingkat pengungkapan corporate social responsibility dan nilai perusahaan pada perusahaan konstruksi yang terdaftar di BEI periode 2014-2016. Pengukuran yang digunakan dalam penelitian ini adalah nilai minimum, maximum, mean, dan standar deviasi (Ghozali, 2007).

\section{Uji Asumsi Klasik}

\section{Uji Normalitas}

Uji normalitas bertujuan untuk menguji apakah dalam model regresi, variabel penganggu atau residual memiliki distribusu normal. Pengujian ini dapat dilakukan dengan Kolmogorov-Smirnov. Apabila pada 
Kolmogorov-Smirnov nilai signifikansi lebih besar dari 0,05 maka data telah terdistribusi dengan normal. Sebaliknya apabila nilai signifikansi lebih kecil dari 0,05 maka data tidak terdistribusi dengan normal (Ghozali, 2007).

\section{Uji Heteroskedastisitas}

Uji heteroskedastisitas bertujuan untuk menguji apakah dalam model regresi terjadi ketidaksamaan variance dari residual satu pengamatan ke pengamatan yang lain. Jika variance dari residual satu pengamatan ke pengamatan yang lain tetap, maka disebut homoskedastisitas dan jika berbeda disebut heteroskedastisitas. Model regresi yang baik adalah yang homoskedastisitas atau tidak terjadi heteroskedastisitas. (Ghozali, 2007). Untuk melihat ada atau tidaknya masalah heteroskedastisitas bisa dilihat dari nilai signifikansi korelasinya, apabila nilai signifikansinya lebih besar dari 0,05 , maka dapat disimpulkan bahwa model regresi tidak ditemukannya masalah heteroskedastisitas.

\section{Uji Multikolinieritas}

Uji multikolinearitas bertujuan untuk mengetahui apakah terdapat interkorelasi (hubungan linear) antara variabel-variabel indipenden yang terdapat dalam model regresi. Model regresi yang baik seharusnya tidak terdapat multikolinaritas antar variabel indipenden. Variabel-variabel indipenden dalam model regresi dikatakan mengalami multikolinaritas apabila VIF (variance inflation factor) lebih besar dari 10. Sebaliknya apabila VIF lebih kecil dari 10 maka tidak terdapat multikolinaritas dalam model regresi (Ghozali, 2007).

\section{Uji Autokorelasi}

Uji autokorelasi bertujuan untuk menguji apakah dalam suatu model regresi terdapat korelasi antara kesalahan yang mengganggu pada suatu periode dengan kesalahan pada periode sebelumnya. Prasyarat yang harus terpenuhi dalam model regresi adalah tidak adanya autokorelasi. Alat uji yang digunakan adalah Durbin-Watson Test (DW). Jika nilai Durbin Watson berada antara -2 dan +2 , dapat disimpulkan bahwa persamaan regresi tidak terjadi autokorelasi (Santoso, 2006).

\section{Pengujian Hipotesis}

\section{Regresi Linear Sederhana}

Untuk mengetahui bagaimana pengaruh kedua variabel, penelitian menggnunakan teknik Analisis Regresi Sederhana. Analisi Regresi Sederhana Linier digunakan untuk mengetahui perubahan yang terjadi pada variabrl Y (Dependen), nilai variabel dependen berdasarkan nilai indipenden (variabel X) yang diketahui. Dengan menggunakan analisis regresi linier maka akan mengukur perubahan variabel terikat berdasarkan perubahan variabel bebas. Analisis regresi linier dapat digunakan untuk mengetahui perubahan pengaruh yang akan terjadi berdasarkan pengaruh yang ada pada periode waktu sebelumnya.

Dalam analisi regresi, data yang telah dikumpulkan kemudian dianalisis dengan menggunakan 
analisis statistik yakni Analisis Regresi Linier Sederhana

$\mathrm{Y}=\alpha+\beta 1 \mathrm{X} 1+\mathrm{e}$

Keterangan :

$\mathrm{Y}=$ nilai perusahaan

$\alpha=$ Bilangan konstanta

$\beta 1=$ koefisien Regresi CSR

$\mathrm{X}=$ Corporate social

responsibility (CSR)

$\mathrm{e}=$ faktor error

(Sumber : Sugiono, 2009:204)

\section{Uji t (Parsial)}

Uji statistik $\mathrm{t}$ dilakukan untuk menunjukkan seberapa jauh pengaruh satu variabel independen secara individual dalam menerangkan variasi variabel dependen. Uji t dapat dilakukan dengan melihat nilai signifikansi t pada output hasil regresi menggunakan SPSS dengan significance level 0,05 ( $\alpha=5 \%)$ jika nilai signifikansi lebih besar dari $\alpha$ maka hipotesis ditolak (koefisien regresi tidak signifikan), yang berarti secara individual variabel independen tidak mempunyai pengaruh yang signifikan terhadap variabel dependen. Jika nilai signifikansi lebih kecil dari $\alpha$ maka hipotesis diterima (koefisien regresi signifikan), yang berarti secara individual variabel independen mempunyai pengaruh yang signifikan terhadap variabel dependen (Ghozali, 2007).

\section{Uji F (Simultan)}

Uji signifikansi simultan (uji statistik F) dilakukan untuk menguji apakah model regresi yang digunakan fit. Dasar pengambilan keputusannya bisa dilihat dari nilai signifikansinya, apabila nilai signifikansinya kecil dari 0,05 maka variabel independen mempengaruhi variabel dependen secara bersama-sama (Ghozali, 2007).

\section{Uji Determinasi}

Pengujian determinasi pada regresi linear sering diartikan sebagai seberapa besar kemampuan semua variabel bebas dalam menjelaskan varians dari variabel terikatnya. Secara sederhana koeefisien korelasi (R), atau langsung melihat angka pada bagian R Square. Perhitungan nilai koefisien determinasi ini diformulasikan sebagai berikut :

$$
\mathrm{R}=\frac{\mathrm{ESS}}{\mathrm{TSS}}
$$

Keterangan :

$\mathrm{R}^{2} \quad=$ Koefisien Determinasi

ESS = Explainned Sum Of Squared

TSS $=$ Total Sum of

Squared

Penggunaan R Squre (R Kuadrat) sering menimbulkan permasalahan, yaitu bahwa nilainya akan selalu meningkat dengan adanya penambahan variabel bebas dalam suatu model. Hal ini akan menimbulkan bias, karena jika ingin memperoleh model dengan $\mathrm{R}$ tinggi, seorang peneliti dapat dengan sembarangan menambahkan variabel bebas dan nilai $\mathrm{R}$ akan meningkat, tidak tergantung apakah variabel bebas tambahan itu berhubungan dengan variabel terikat atau tidak.

Oleh karena itu banyak peneliti yang menyarankan untuk menggunakan Adjusted R Square. Interprestasinya sama dengan $R$ Square, akan tetapi nilai Adjusted $\mathrm{R}$ Square dapat naik dan turun dengan adanya penambahan variabel baru, tergantung dari korelasi antara variabel bebas tambahan tersebut dengan variabel terikatnya. Nilai 
Adjusted R Square dapat bernilai negatif, sehingga jika nilai nya negatif maka nilai tersebut dianggap 0 , atau variabel bebas sama sekali tidak mampu menjelaskan varian dari variabel terikatnya (Statistik, 2011). atas, $\begin{array}{cc}\text { Berdasarkan } & \text { penjelasan di } \\ \text { mentuk } & \text { mentukan }\end{array}$ determinasinya pada penelitian ini akan digunakan nilai Adjusted $\mathrm{R}$ Square.

\section{HASIL PENELITIAN}

\section{Statistik Deskriptif}

Tabel 1

\begin{tabular}{|c|c|c|c|c|c|}
\hline & $\mathrm{N}$ & Minimum & Maximum & Mean & Std. Deviation \\
\hline $\begin{array}{l}\text { TOBINS } \\
\text { CSR } \\
\text { Valid N (listwise) }\end{array}$ & $\begin{array}{l}45 \\
45 \\
45\end{array}$ & $\begin{array}{l}.06 \\
.11\end{array}$ & \begin{tabular}{|r|}
2.34 \\
.46
\end{tabular} & $\begin{array}{l}.7011 \\
.2442\end{array}$ & \begin{tabular}{|l|}
.48174 \\
.08134
\end{tabular} \\
\hline
\end{tabular}

Sumber : Diolah dengan SPSS 20.0

Berdasarkan pengujian statistik deskriptif yang dijelaskan dalam tabel 4.26, dapat diketahui bahwa variabel nilai perusahaan yang diukur dengan Tobin's Q mempunyai nilai tertinggi sebesar 2,34 dan nilai terendah 0,06 dengan rata-rata

\section{Menilai Kelayakan Model Regresi}

\section{Uji Normalitas}

Uji kualitas data yang pertama dalam penelitian ini dilakukan dengan melakukan uji normalitas data melalui analisis statistik dengan menggunakan uji statistik non parametrik One-Sample Kolmogorov-Smirnov. Hasil pengujian disajikan pada tabel 4.27. perusahaan 0,7011 dan standar deviasi perusahaan sebesar 0,48174.

Dari analisis deskriptif CSR sebagai variabel indipenden mempunyai nilai tertinggi sebesar 0,46 dan nilai terendah sebesar 0,11 dengan rata-rata 0,2442 dan standar deviasi 0,8134 .

Apabila pada Kolmogorov-Smirnov nilai signifikansi lebih besar daripada 0,05 maka telah terdistribusi dengan normal. Sebaliknya apabila nilai signifikansi lebih kecil dari 0,05 maka data tidak terdistribusi dengan normal (Ghozali, 2007). Untuk melihat uji normalitas dari masing-masing variabel dapat dilihat dibawah ini

Tabel 2

One-Sample Kolmogorov-Smirnov Test

\begin{tabular}{|ll|r|r|}
\hline & & TOBINS & CSR \\
\hline Normal Parameters ${ }^{\mathrm{a}, \mathrm{b}}$ & Mean & 45 & 45 \\
& Std. Deviation & .2011 & .2442 \\
& Absolute & .112 & .08134 \\
Most Extreme Differences & .112 & .130 \\
& Positive & -.062 & .130 \\
& Negative & .122 & .070 \\
& & .0730 & $.056 \mathrm{c}$ \\
Test Statistic & & & \\
Asymp. Sig. (2-tailed) & & & \\
\hline
\end{tabular}


a. Test distribution is Normal.
b. Calculated from data.
c. Lilliefors Significance Correction.

Sumber : Diolah dengan SPSS 20.0 tidaknya ketidaksamaan varian dari residual pada model regresi. Prasyarat yang harus terpenuhi dalam model regresi adalah tidak adanya masalah heteroskedastisitas. Pada penelitian ini, pembahasan akan dilakukan menggunakan uji Glejser. Uji Glejser dilakukan dengan cara meregresikan antara variabel independen dengan nilai absolut residualnya. Jika nilai signifikansi antara variabel independen dengan absolut residual lebih dari 0,05 maka tidak terjadi masalah heteroskedastisitas

digunakan untuk mengetahui ada atau

Tabel 3

Hasil pengujian Heteroskedastisitas Coefficients(a)

\begin{tabular}{|c|c|c|c|c|c|}
\hline \multirow[b]{2}{*}{ Model } & Unstandardized Cc & oefficients & \begin{tabular}{|l} 
Standardized \\
Coefficients
\end{tabular} & & \multirow[b]{2}{*}{ Sig. } \\
\hline & $\mathrm{B}$ & Std. Error & Beta & $\mathrm{T}$ & \\
\hline (Constant) & $2.196 \mathrm{E}-16$ & .206 & & .000 & 1.000 \\
\hline CSR & .000 & .802 & .000 & .000 & 1.000 \\
\hline
\end{tabular}

a. Dependent Variable: ABS_RES

Sumber : Diolah dengan SPSS 20.0

Berdasarkan tabel 3 diatas, dapat diketahui bahwa nilai signifikansi variabel independen adalah 1,000. Dengan demikian dapat disimpulkan

\section{Uji Multikolinearitas}

Uji multikolinearitas digunakan untuk mengetahui ada atau tidaknya hubungan linear antar variabel indipenden dalam model regresi. Uji multikolinearitas dilakukan dengan menghitung nilai Variance Inflation Factor (VIF) dari tiap-tiap variabel indipenden. Variabel-variabel bahwa tidak terjadi masalah heteroskedastisitas pada model regresi, karena signifikansinya besar dari 0,05 .

indipenden dalam model regresi dikatakan mengalami multikolinearitas apabila VIF lebih besar dari 10 dan sebaliknya apabila VIF lebih kecil dari 10 tidak terdapat multikolinearitas dalam model regresi (Ghozali, 2007). 
Tabel 4

Hasil Pengujian Multikolinearitas

Coefficients(a)

\begin{tabular}{|l|l|l|l|}
\hline \multirow{2}{*}{} & \multicolumn{2}{|c|}{ Collinearity Statistics } & \multirow{2}{*}{ Keterangan } \\
\cline { 2 - 3 } & Tolerance & VIF & Tidak ada \\
(Constant) & & & $\begin{array}{l}\text { Masalah } \\
\text { Multikolinearitas }\end{array}$ \\
\hline CSR & 1,000 & 1,000 & \\
& & &
\end{tabular}

Sumber : Diolah dengan SPSS 20.0

Berdasarkan tabel 4 diatas terlihat bahwa nilai VIF adalah sebesar 1,000 untuk variabel CSR. Dengan demikian, hasil analisis menunjukkan tidak adanya masalah

\section{Uji Autokorelasi}

Prasyarat yang harus terpenuhi dalam model regresi adalah tidak adanya autokorelasi. Alat uji yang digunakan adalah Durbin-Watson Test (DW). Jika nilai Durbin Watson berada antara -2 dan +2 maka dapat multikolinier. Nilai VIF kurang dari 10 menunjukkan kolerasi antar variabel indipenden masih bias di tolerir.

disimpulkan bahwa persamaan regresi tidak terjadi autokorelasi (Santoso, 2006). Pada tabel berikut ini disajikan uji autokorelasi untuk masing-masing model regresi.

Tabel 5

Durbin-Watson Seluruh Perusahaan Sampel Model Summary(b)

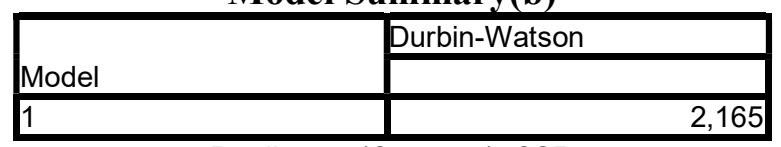

a. Predictors: (Constant), CSR

b. Dependent Variable: TOBINS

Dari hasil pengolahan data pada tabel 4.30, diperoleh nilai Durbin-Watson berada antara -2 dan +2 , maka dapat disimpulkan bahwa tidak terjadi autokorelasi pada model regresi yang digunakan dalam penelitian ini.

Menilai Signifikansi Koefesien Regresi

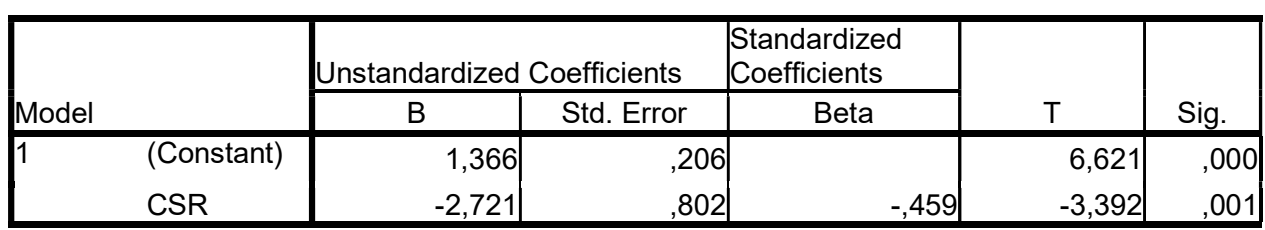

Dependent Variable: TOBINS

Sumber : Diolah dengan SPSS 20.0 
Berdasarkan hasil analisis regresi linear sederhana diperoleh nilai t hitung untuk variabel CSR diketahui nilai signifikansi sebesar 0,001 . Karena nilai signifikansi lebih kecil dari 0,05 maka hasil ini menunjukkan bahwa corporate social responsibility (CSR) berpengaruh secara signifikan terhadap nilai perusahaan. Dengan demikian H1 diterima. Variabel CSR (X) mempunyai $\mathrm{t}$ hitung yakni 3.392 dengan $\mathrm{t}$ tabel yakni 2.01669. Jadi $\mathrm{t}$

\section{PEMBAHASAN}

Pertanggung jawaban sosial perusahaan dapat diungkapkan di dalam laporan yang disebut sustainability reporting (laporan keberkelanjutan). CSR dapat menjadi keberlanjutan apabila program yang di buat oleh suatu perusahaan benar-benar merupakan komitmen bersama segenap unsur yang ada dalam perusahaan itu sendiri. Tentunya, tanpa adanya Berdasarkan teori signal ang memiliki informasi bagus tentang perusahaan berupaya menyampaikan informasi tersebut kepada investor luar agar saham perusahaan meningkat (Sugiarto, 2009).

Pelaksanaan

CSR diharapkan akan mampu menaikkan nilai perusahaan dilihat dari harga saham dan laba perusahaan (earning) sebagai akibat dari para investor yang menanamkan saham di perusahaan, karena kegiatan CSR merupakan keberpihakan perusahaan terhadap masyarakat. Sehingga masyarakat akan mampu memilih produk yang baik yang di nilai tidak hanya barangnya saja, hitung $>t_{\text {tabel }}$ dapat disimpulkan bahwa variabel CSR $\left(\mathrm{X}_{1}\right)$ memiliki kontribusi terhadap nilai perusahaan (Y). Nilai $t$ negatif menunjukkan bahwa CSR (X) mempunyai hubungan yang berlawanan arah terhadap nilai perusahaan (Y). Sehingga dapat disimpulkan bahwa terdapat pengaruh signifikan antara CSR (X) terhadap nilai perusahaan (Y). komitmen dan dukungan penuh antusias karyawan akan menjadikan program-program tersebut bagaikan program penebusan dosa dari pemegang saham belaka, dengan melibatkan keryawan secara intensif maka nilai dari programprogram tersebut akan memberikan arti tersendiri yang sangat besar bagi perusahaan.

(signalling theory), manajer y tetapi juga melalui tata kelola perusahaannya. Kegiatan CSR sendiri merupakan bagian dari tata kelola perusahaan yang baik. Pada saat masyarakat yang menjadi pelanggan memiliki penilaian yang positif terhadap perusahaan, maka mereka akan loyal terhadap produk yang dihasilkan. Sehingga hal ini akan mampu menaikkan citra perusahaan yang direfleksikan melalui harga saham yang akan meningkat

Dari hasil analisis Uji Hipotesa pada tingkat kepercayaan $\alpha$ $=0,05$ terbukti bahwa variabel Corporate Social Responsibility (CSR) berpengaruh negatif dan 
signifikan terhadap nilai perusahaan konstruksi yang terdaftar di Bursa Efek Indonesia. Hal ini terlihat dari nilai regresi adalah $-2,721$ dan nilai signifikansi adalah 0.001 yang bernilai lebih kecil dari $\alpha=0,05$, oleh karena itu keputusan adalah $\mathrm{H}_{1}$ diterima.

$$
\text { Hasil output SPSS }
$$

menunjukkan bahwa CSR memiliki pengaruh negatif bagi nilai perusahaan. Ini menunjukkan bahwa semakin tinggi CSR perusahaan maka akan semakin rendah pula nilai perusahaannya. Hasil ini mendukung teori yang dikemukakan oleh Modigliani dan Miller serta relevan dengan penelitian yang dilakukan oleh Suranta (2007).

Hal ini mungkin disebabkan oleh pengungkapan corporate social responsibility (CSR) yang terlalu tinggi dapat menurunkan tingkat laba perusahaan yang disebabkan semakin besar biaya yang dikeluarkan oleh perusahaan, sehingga akan berpengaruh terhadap jumlah deviden yang diterima oleh investor. Maka dari pada itu dapat berpotensi menurunkan minat para investor.

UU no.40 tahun 2007 tentang

Perseroan Terbatas yang disahkan oleh pemerintah pada 20 Juli 2007 dan mulai diberlakukan pada 16 Agustus 2007 yang mana isi dari undang-undang tersebut mengatur kewajiban perusahaan untuk memprogramkan dan melaksanakan tanggung jawab sosial perusahaan. Berdasarkan hasil indeks pengungkapan, terjadi peningkatan terhadap tiga fokus pengungkapan corporate social responsibility (CSR) oleh 9 perusahaan sampel tersebut. Dengan diberlakukannya UU tersebut ternyata cukup efektif untuk meningkatkan tanggung jawab sosial perusahaan.

\section{KESIMPULAN}

Berdasarkan analisis yang telah dilakukan, diperoleh hasil pengujian hipotesis menunjukkan bahwa variabel corporate social responsibility (CSR) terdapat pengaruh yang negatif dan signifikan variabel corporate social responsibility (X) terhadap Nilai Perusahaan. Dengan meningkatnya corporate social responsibility (CSR) maka nilai perusahaan akan menurun sebesar $-2,721$ atau 272,1\%. Begitupun sebaliknya Dengan menurunnya corporate social responsibility (CSR) maka nilai perusahaan akan meningkat sebesar 2,721 atau $272,1 \%$.

Hasil ini mendukung teori yang dikemukakan oleh Modigliani dan Miller serta relevan dengan penelitian yang dilakukan oleh Suranta (2007), Nurlela dan Islahudin (2008). Hal ini mungkin disebabkan oleh pengungkapan corporate social responsibility (CSR) yang terlalu tinggi dapat menurunkan tingkat laba perusahaan yang disebabkan semakin besar biaya yang dikeluarkan oleh perusahaan, sehingga akan berpengaruh terhadap jumlah deviden yang diterima oleh investor. Maka dari pada itu dapat berpotensi menurunkan minat para investor.

\section{DAFTAR PUSTAKA}

\author{
BEI.2016 Annual Report. Diakses \\ dari \\ http://www.BEI.co.id.
}


Bastian, Indra. 2008. Akuntansi

Sektor Publik: Suatu Pengantar.

Jakarta: Erlangga.

Betharia. 2011. "Pengaruh

Profitabilitas Terhadap

Nilai Perusahaan

Dengan Pengungkapan

Corporate Social

Responsibility (CSR)

Sebagai Variabel

Moderator Pada

Perusahaan

Pertambangan Yang

Terdaftar di BEI.

Download definisi Corporate Social

Responsibility (CSR) di

http://id.wikipidia.org/

wiki/csr.

Download indikator pengungkapan

CSR menurut GRI di

http://www.globalreport

ing.org.

Eugene Brigham, F dan Houston.

Joel, F. 2007.

Manajemen Keuangan.

Buku satu edisi

kedelapan

diterjemahkan oleh

Dodo Suhartono dan

Wibowo. Jakarta:

Erlangga.

Brigham dan Houston. 2010. Dasar-

Dasar Manajemen

Keuangan Buku 1 (Edisi

II). Jakarta: Salemba Empat.

Tandelilin, Eduardus. 2012. Analisis

Investasi dan

Manajemen Portofolio

Edisi pertama,

Yogyakarta: BPFE-

Yogyakarta.

Ghozali, Imam. 2007. Aplikasi

Analisis Multivariate dengan Program SPSS

Cetakan IV. Semarang;

\section{Badan Penerbitan \\ Universitas \\ Diponegoro.}

Hadi, Nur. (2011). Corporate Social

Responsibility edisi Pertama.

Yogyakarta :

Graha Ilmu.

Hartono, A dan Martono. 2005. Manajemen Keuangan. Yogyakarta.

http://ejournal.unud.ac.id/absrack/ok \%2520wirakusumayuniangsih.pdf

Indonesian Capital Market Directory, 2014

\begin{tabular}{c}
\hline 2015 \\
\hline 2016
\end{tabular}

Mulyadi. 2007.Sistem Terpadu

Pengelolaan Kinerja Personel

Berbasis Balanced

Scorecard . Yogyakarta: STIM YKPN.

Nurlela dan Islahudin. 2008. "Pengaruh Corporate Social Responsibility (CSR) terhadap Nilai Perusahaan dengan Presentase Kepemilikan Manajemen sebagai Variabel Moderating". Simposium Nasional Akuntansi XI.

Saidi, 2007. "Faktor-faktor yang mempengaruhi struktur modal pada perusahaan manufaktur go public di BEJ tahun 1997-2002". Jurnal Bisnis dan Ekonomi, Vol. 11 No. 1, pp. $44-58$

Samsinar, A .Haerani, S dan Pagalung, G.2009.’Pengaruh Pengungkapan 


\begin{tabular}{l} 
Corporaterial \\
Responsibility Terhadap \\
Kinerja Keuangan \\
Perusahaan dan Harga \\
Saham".http://www.pas \\
ca.unhas.ac.id/jurnal/fil \\
\hline e/38fa14eea5a1179442f \\
\hline ce7e9d761.pdf. \\
A.2007. Manajemen \\
Keuangan Teori dan \\
Aplikasi. Badan \\
Penerbit UGM : \\
Yogyakarta.
\end{tabular}

Sembiring, Edi. 2007. "Pengaruh Karakteristik

Perusahaan Terhadap Pengungkapan

Tanggung Jawab Sosial : studi empiris pada perusahaan yang tercatat di BEI)". Tesis.Semarang

Universitas

Diponegoro.

Singarimbun, Masri dan Sofian Effendi (editor). 1995. Metode Penelitian Survey. Jakarta: LP3ES.

Sugiono. 2007. Metode Penelitian Administrasi. Bandung. Alfabeta

Sugiono. 2012. Metode Penelitian Pendidikan Kuantitatif, Kualitatif dan R\&d. Bandung:CV. ALfabeta

Sugiyono, 2014. Metode Kuantitatif. Kualitatif dan R\&D. Bandung CV. Alfabeta

Suharto, Edi. 2007. Corporate Social Responsibility : What is and Benefit for Corporate. http://www.policy.hu/suharto.

Sunreni. 2010. "Perusahaan Sebelum dan Sesudah Penerapan Corporate Social
Responsibility Terhadap

Profitabilitas Industri

Pertambangan Yang

Terdaftar di BEI".

Suranta, Sri. 2007. "Analisis

Pengaruh

Pengungkapan

informasi

Pertanggungjawaban

sosial (Corporate Social

Responsibility) terhadap

firm Value pada

Perusahaan Manufaktur

di Indonesia".

http://www.digilip.ui.ac

.id/opac/theme/libri2/ab

strakpdf.

Wahyudi dan Azhari. 2008.

Corporate Social

Responsibility : Prinsip,

pengaturan, dan

implementasi. Inspire

Wirakusuma, M.G dan Yuniangsih, N.W. 2008. "Pengaruh

Kinerja Keuangan

Terhadap Nilai

Perusahaan Dengan

Pengungkapan

Corporate Social

Responsibility dan Good

Coorporate

Governance sebagai variabel moderasi".

Yuliana, Purnomisidi dan

Sujoharsono. 2008.

"Pengaruh Karakteristik

Perusahaan Terhadap

Pengungkapan

Corporate Social

Responsibility dan

Dampaknya Terhadap

Reaksi Investor". Jurnal

Akuntansi dan

Keuangan Indonesia

Volume 5-Nomor 1. 
Jurnal Manajemen dan Kewirausahaan, Volume 9, Nomor 3, September 2018

ISSN 2086-5031

E-ISSN 2615-3300

DOI 10.31317

Yusrina. 2010. "Pengaruh Leverage

dan Profitabilitas

Perusahaan Terhadap

Corporate Social

Responsibility (CSR)

Pada Perusahaan

Manufaktur yang $G O$

Public di Indonesia. 